\title{
Impacting Student Success: A Practical Guide to Assessing Library Services at the Community College Level
}

\author{
Faith Bradham \\ Bakersfield College, USA
}

\begin{abstract}
Library assessment is a well-established necessity for proving a library's worth to administration. Yet few documented library assessments focus on assessment of community college library services, instead concentrating on library collections at four-year universities. Library services can include reference, information literacy instruction, and library outreach, all of which directly tie to students' academic success. This paper seeks to fill the gap in the literature on community college assessment of library services by presenting the results of a mixed methods assessment of library services at Bakersfield College during the fall 2017 semester. The results of this study were quite positive, although gaps in service were identified and addressed post-assessment. The library plans to continue assessing its services every three years with this model of assessment. This assessment is replicable for any community college library that wishes to begin its own formal assessment practices, as well as any academic library interested in beginning to assess its services.
\end{abstract}

\section{Assessing Community College Library Services}

With the recent completion of ACRL's Assessment in Action program, academic library assessment has become a hot topic. ${ }^{1}$ Although always integral for service-oriented professions, assessment often serves a unique purpose for academic libraries in that it can also show how the library and its services impact student success and the college as a whole. The study results published in Assessment in Action document the ways in which libraries contribute to student success at their colleges or universities, highlighting how necessary it is for library services to respond and evolve to the needs of their individual campuses. ${ }^{2}$

Historically, library assessments have focused on library collections rather than library services. ${ }^{3}$ However, an argument can be made that a more effective form of library assessment focuses instead on student usage of library services and the degree to which student library usage relates to academic success. ${ }^{4}$ Although many library assessments show a link between student success and the academic library, it is difficult to find studies that focus on this link at community colleges rather than at four-year colleges and universities. When looking at the list of the 203 institutions participating in the Association of College \& Research Libraries'

Assessment in Action program, less than $15 \%$ of these institutions are community or technical colleges. ${ }^{5}$ This shows a clear gap in the research on assessing library services at the community college level. In addition, the mission of community colleges in California focuses on teaching and learning rather than research. As a result, community college libraries are less concerned with higher level research and more concerned with providing the breadth of basic services necessary for community college student success, proving the need for assessment of those services. This paper demonstrates methods for a full-scale assessment of community college library services, taking an assessment done during fall 2017 for the Bakersfield College Grace Van Dyke Bird Library as its paradigm.

\section{The Bakersfield College Grace Van Dyke Bird Library}

Bakersfield College (BC) is one of 114 California community colleges. Bakersfield is located in Kern County, part of the highly agricultural San Joaquin Valley. This area has a low socio-economic rate, with a poverty rate approaching $23 \%$ and fewer than $16 \%$ of adults obtaining a bachelor's degree or higher by the age of $25 .^{6}$ As of the 2016-2017 academic year, the college had an FTE of about 15,500 with a very diverse, nontraditional student population. $\mathrm{BC}$ also awards the highest number of degrees of any institution of higher education in Kern County. ${ }^{7}$ Many of the close to 30,000 students on campus stream through the library's doors every day, interacting with the librarians multiple times per week-much more than they interact with their professors and counselors. Moreover, due to the nature of BC's student population, many students who 
come to our library have never been in a library before or have not entered a library for several years or decades. As a result, our library services do not simply orient them to the differences between an academic library and a high school or public library, but introduce them to the library as a concept.

Since the library teaches both for-credit and not-for-credit courses, the BC library reports to a vice president of instruction at the college. However, it is colloquially considered part of campus' Student Services along with non-academic units such as the Writing Lab and the Tutoring Center. There are five full-time tenuretrack faculty librarians on staff at the main campus library, along with three adjuncts. Of the five full-time librarians, one serves as a technical services librarian (and is currently our chair), while the rest serve simultaneously as reference, instruction, liaison, and outreach librarians. The library currently offers access, reference, instruction, and technology services. However, before fall 2017, we had no formal measurement for each of these categories. Without this measurement, we had no evidence of library use or perception other than a once-per-decade collection inventory, had no data to provide to administration regarding the impact of the library on student success, and were lacking in concrete data we could use to make staffing or technology requests.

\section{Assessing Library Services at Bakersfield College}

During spring 2017, the library conceptualized its assessment design. We focused on two questions to assess during the fall 2017 semester:

1. Does the current level of library services adequately fulfill the needs of the student population at Bakersfield College?

2. How should the library change or enhance its services to better meet the needs of its community?

To measure these two questions, the library designed a mixed-methods assessment that utilized quantitative usage statistics as well as qualitative surveys targeted to students and faculty at the college.

Rather than choosing to assess one week or month of the semester, we decided to assess our services across the entire semester in order to establish an assessment benchmark. Several tools helped us gather library usage statistics. Since the library does not own door-counting software, I took a manual headcount of students four times per day (9:30 a.m., 12:30 p.m., 3:30 p.m., and 5:30 p.m.), library hours permitting. Our circulation staff kept track of study room usage each week and tallied up the weekly and semesterly totals in a report at the end of the semester. These two counts helped us measure overall usage of library space. I also pulled end-of-semester reports on printer and copier usage, e-book and database usage, and circulation statistics. We used these to measure our technology and access services.

Measuring reference and instruction services required a combination of quantitative and qualitative instruments. The library uses the Springshare platform to collect reference statistics, which meant I could easily pull reports at the end of the semester to measure the number, type, length, and frequency of reference questions throughout the semester. However, to measure student perception of our reference services, I gave a targeted reference survey (via SurveyMonkey) to any student who asked a reference question during October 2017. ${ }^{8}$ I chose this month because October is one of our busiest months and I hoped I would be able to collect a maximum number of survey responses this way. To measure our library instruction, I not only tallied the number of library research skills workshops and library orientations (one-shots) we taught throughout the semester, but I also asked each librarian who taught instruction sessions to give me a headcount for each session they taught during the semester. ${ }^{9}$ We captured student perception of the research skills workshops by asking each student who attended a workshop to fill out a brief paper survey, while we captured faculty perception of library orientations by sending a SurveyMonkey survey to all faculty who brought their classes into the library that semester. ${ }^{10}$ This survey asked faculty about their experience with the orientation and whether they felt it had helped their students. 
I also sent out a broad SurveyMonkey survey on library perception to the all-campus Listserv during October $2017 .^{11}$ This survey measured the library perception of any student who had used the library recently or in the past. Finally, I sent a SurveyMonkey survey on library perception to the all-faculty Listserv in order to include the perception of faculty who may not have requested a library orientation during fall 2017.

\section{Assessment Results}

I compiled the results of this assessment during spring 2018. Since so much of the data was in the form of usage statistics, and since I used a survey software that easily creates reports and data tables, this process was quite simple. The results of our assessment were far more positive than we had anticipated. Based on these results, the library is both highly used by the campus community and very positively perceived by both students and faculty at Bakersfield College. The final headcount for the semester was over 40,000, with an average of 122 students in the library at all times and a record headcount of 333 students at 12:30 p.m. on October 3, 2017. Our five study rooms were checked out a total 1,550 times during the semester, or just about 16 times per day. The headcount and study room data have been extremely helpful as a tool to prove the sheer volume of BC student presence in the library.

We also recorded over 5,000 reference questions, which is just over 300 per week. The reference data helped us identify the busiest times for reference, which led us to reconfigure staffing at the reference desk. In addition, we taught 94 different library orientations to 2,180 students over the semester as well as 44 research skills workshops to 343 students, for a total of 2,523 students taught over the semester. This means that about $10 \%$ of the total student population received some form of library instruction during fall 2017.

The survey results show that both faculty and students feel positively about library services. The general survey to all BC students shows that $35 \%$ of respondents use the library multiple times per week, and over $82 \%$ of the respondents indicated that one of their primary reasons for using the library was as a quiet space to do homework, with database use coming in second at $63 \%$. This drives home the fact that the library is one of the only spaces many of our students feel they have to complete their homework. Many of our students live with family or have children, and they find that they have too many demands on their attention at home to complete their school work. The library as a space is vital for them.

About $25 \%$ of the respondents for the general survey and the targeted reference survey indicated that they ask librarians a question about once a week, while the targeted reference survey responses revealed that librarians were perceived as helpful $90 \%$ of the time. Moreover, students were happy with their access to reference librarians $100 \%$ of the time. These results were a phenomenal affirmation of our reference services; we were particularly pleased that our students find reference desk hours sufficient for their needs. On the instructional side of things, when students were asked to rate how helpful the information they learned would be for their classes, the average answer was a 4.7 out of 5 , with 1 being "not at all" and 5 being "essential." All faculty survey respondents who requested orientations said that the orientation their students received met their expectations, and over $85 \%$ indicated that they had noticed an improvement in their students' research skills after the orientation. We were very happy with these instruction results.

Although the primary goal of these surveys was to gain an understanding of library perception on campus, I had a secondary goal of using them to create a way to capture the library's impact on student success at Bakersfield College. When creating the assessment as a whole, I had hoped to be able to track the GPAs of students who had participated in library instruction in order to compare their GPAs with overall GPA statistics on campus. Other community colleges have set a precedent for this type of tracking-Austin Community College in particular has a wonderful model. ${ }^{12}$ However, when I approached the college about this, the BC Admissions \& Records Department cited FERPA concerns and denied my request. Given this development, I decided to implement the library's student surveys on library perception as a way to gain data on library impact on student success. I added a question to the general student survey related to each of BC's Institutional Learning Outcomes (ILOs) to help determine whether students perceived that the library had helped them achieve these learning outcomes. For every ILO, at least $40 \%$ of students stated that they "strongly agreed" that the library had helped them achieve this outcome, while fewer than $5 \%$ disagreed that 
the library had helped them achieve any particular ILO. While this data is self-reported, we were quite happy with these results in the absence of access to student grades.

As a whole, the library found the results of this assessment incredibly helpful. We were able to use the assessment data we gathered as key evidence during our campus' accreditation renewal in fall 2018. I also presented the results of this assessment to the campus' Assessment Committee as a method for nonacademic units on campus to assess their services. Based on preliminary discussions within the library, we plan to assess our services every third year with this model. We came to this number based on the fact that all California community colleges follow a six-year accreditation cycle through the Accrediting Commission for Community and Junior Colleges (ACCJC). By assessing library services every third year, we will ensure that our services are assessed twice during each six-year accreditation cycle.

\section{Addressing Gaps in Library Service}

While there were almost no negative responses to any of our surveys, we did identify two gaps in our services after analyzing the survey data. The first was a lack of consistently quiet study space for students in the library and the second was a lack of awareness among faculty of the services they could use at the library. The library began addressing these issues during fall 2018.

As stated previously, over $80 \%$ of surveyed students stated that their primary reason for using the library was as a quiet space to complete homework, with about $45 \%$ of students coming to the library for this reason multiple times per week. Yet a consistent response to our open-ended survey question asking students whether the library meets their needs as a student was that the library is often too crowded or too noisy for students to be able to work effectively (in fact, one student compared our noise level to the campus cafeteria!). As community college librarians, we know that the library is one of the only places on campus where students can study-unlike residential campuses, BC has no student union and study space is very limited at the writing and tutoring centers. This means that it is not only very important for students be able to study quietly in the library, but also for students to have space for group study (as demonstrated by the extremely high usage of our study rooms). To help with the noise level while still allowing space for group study, we instituted noise zones throughout the library. The library is contained on one floor, so we cannot use the easy solution of one quiet and one group study floor; instead, we moved all large tables to the front of the library and called the front half of the library our "hushed-talking zone" where students may talk quietly while studying together. The back half of the library is the "no-talking zone" for completely silent study. To help shift the culture of the library to reflect these two zones, we placed prominent signage at the entrances to each zone, and the librarians regularly walk around the library to check on noise levels. Noise complaints have decreased this semester now that students have a more consistent idea of how to use the library, and students seem much happier now that they have a clear way to tell how they should be using the library.

We discovered the second gap in services, the lack of awareness of library services among BC faculty, as a result of the all-faculty survey sent out at the end of fall 2017. In it, we identified five services faculty can use at our library (library workshops, customized library orientations, reserve textbooks, ordering coursesupportive books, and collaborating with librarians on research assignments) and asked faculty how often they used these services. In every case, at least $13 \%$ of faculty were not aware of the service, and in three cases, nearly $45 \%$ of faculty were not aware of the service. To help with this, the library has been more proactive in advertising how faculty can use its services. The last newsletter of the 2017-18 year devoted its front page to our different faculty services, and we created a library brochure for faculty that our librarians distribute when they attend department meetings in their liaison areas. We also sent out an email to both full-time and adjunct faculty listing our services at the beginning of fall 2018, and our chair attended the new faculty orientation in fall 2018 to explain our services to the new faculty. We hope this renewed effort helps lessen the gap in faculty knowledge of library services.

\section{A Framework for Assessing Community College Libraries}

While recognizing that this assessment was created for the unique needs of the Bakersfield College Library, this assessment is fully replicable for any community college library that wishes to begin its own formal 
assessment practices and, in fact, for any type of academic library interested in beginning to assess its services. The basic concept remains the same: identify which services you would like to assess and determine which quantitative and qualitative data methods might best work for your library's needs. Relying largely on usage reports and surveys of the campus population is particularly helpful for institutions that do not subscribe to assessment services such as Qualtrics, Ithaka S+R, etc.

The method for measuring library services laid out in this paper can be quite work-intensive, depending on the level of staff at your particular library, but it is extremely useful for gaining as complete a picture of library usage and perception as possible. If your library does not have a baseline for assessing library services, it may be helpful to begin by assessing all services as described here. However, when deciding on assessment design for your own library, it is also important to consider the depth and breadth of your needs: do you need to assess all library services, or would you like to focus only on reference or only on instruction? Do you have the work force and the time to complete daily assessment tasks, or would it be better for your library to focus on usage reports pulled at the end of the semester? Do you have permission to conduct qualitative research on your campus? This last question is often contingent on whether your college has a department of Institutional Effectiveness or an IRB; BC had no IRB when I began designing the assessment, which made the process of determining how to gain consent to conduct human research for this assessment a little tricky.

In addition, community colleges are different than traditional colleges or universities. I say this with no intent to create a sense of rivalry between the two types of institutions; instead, I am referring to the differences in staff, mission, and faculty research support between the two types of institution. While community college librarians might have the same drive for research and assessment as their four-year colleagues, we are generally stretched a little thinner. Whereas a four-year university might have 10 or 100 librarians (including entire librarians dedicated to assessment!), it is quite common for community colleges to have five or fewer librarians who wear many different hats. This means that community college librarians have almost no time for individual research between collection development, reference, teaching one-shots and workshops, and conducting student outreach. In addition, the majority of community colleges do not require research during the tenure process. Since research is not required to gain tenure or promotion, there are significantly fewer institutional services and supports for faculty research at community colleges. As argued at the beginning of this paper, this combination has led to a lack of published assessment for community college libraries.

However, this does not mean community college libraries are doomed to assess less than their university peers. All of the assessment accomplished in this paper was cooperatively conducted by a team of five librarians and four library staff, none of whom were previously trained in library assessment practices. If our library can do it, your library can do it as well! This mindset also applies to smaller colleges or universities in addition to community colleges. Libraries at smaller institutions might feel that their staff would be overwhelmed by a full-scale assessment, and so they might shy away from developing an assessment like the one presented here. Instead, I encourage any type of academic librarian to sit down and develop a list of their library's services, then determine the best way to assess each service, using the examples I have listed in my own assessment as well as any additional assessment you might need.

\section{Conclusion}

Assessing library services makes it possible for the library to have real data on how effective the library is in helping the many students they come into contact with each day. This is helpful not only when communicating the value of the library to campus and district administration, but also when the need for new equipment, more staffing, etc. comes into play. For example, with no assessment data to point to, administration might not place a need for more librarians during a certain time of day at a high value when making budgetary decisions. In addition, lack of assessment data can become a problem during processes like accreditation renewal. Bakersfield College went through its accreditation renewal during fall 2018 and the data from our library assessment was incredibly useful not only for the college's self-assessment report to the accreditors, but also during discussions with the accreditors during the accreditation site visit. Without it, 
we would not have been able to answer questions of how the library assesses the campus' institutional learning outcomes, and how we assess our own program and student outcomes.

Although the act of creating an assessment framework from scratch can seem daunting, my hope is that community college librarians reading this paper will be heartened by the fact that community college assessment of library services is alive and well, and thus feel encouraged to begin their own assessment process. Community college libraries provide a unique service to their campus and their communities and it is important that our efforts are known, quantified, and acknowledged.

-Copyright 2019 Faith Bradham

1. ACRL, "Assessment in Action."

2. Brown, "Documented Library Contributions."

3. Matthews, Library Assessment in Higher Education.

4. Ackerman, "Program Assessment in Academic Libraries," 18; Dickenson, "How Academic Libraries Help"; and Matthews, Library Assessment in Higher Education.

5. ACRL, "Assessment in Action."

6. Data USA, "Kern County, CA" and United States Census Bureau, "Quick Stats."

7. Data USA, "Kern County, CA" and Bakersfield College, "Renegade Scorecard."

8. See Appendix A.

9. See Appendix B.

10. See Appendix C.

11. See Appendix D.

12. Cowling, "Evolution of Assessment at Austin Community College."

\section{Bibliography}

Ackerman, Eric. "Program Assessment in Academic Libraries: An Introduction for Assessment Practitioners." Research \& Practice in Assessment 2 (Summer 2007): 18. https://eric.ed.gov/?id=EJ1062647.

Association of College \& Research Libraries. "Assessment in Action: Academic Libraries and Student Success.” Accessed October 29, 2018. http://www.ala.org/acrl/aia.

Bakersfield College. "Renegade Scorecard." Accessed October 29, 2018. https://www.bakersfieldcollege.edu/scorecard/.

Brown, Karen. "Documented Library Contributions to Student Learning and Success: Building Evidence with Team-Based Assessment in Action Campus Projects.” Association of College \& Research Libraries. April 2016. http://www.ala.org/acrl/sites/ala.org.acrl/files/content/issues/value/contrib utions_y2.pdf.

Cowling, Lisa. "Evolution of Assessment at Austin Community College." Council of Chief Librarians. Fall 2016. https://cclibrarians.org/sites/default/files/2016/workshops/assessment-evolution-accdcowling.pdf.

Data USA. "Kern County, CA.” Accessed October 29, 2018. https://datausa.io/profile/geo/kern-county-ca/.

Dickinson, D. "How Academic Libraries Help Faculty Teach and Students Learn: The Colorado Academic Library Impact Study.” Library Research Service (February 2006): iii. Accessed October 29, 2018. https://eric.ed.gov/?id=ED491390.

Matthews, J. R. Library Assessment in Higher Education. Westport, CT: Greenwood Publishing Group, 2007. 
United States Census Bureau. "Quick Stats: Kern County, California.” Accessed October 29, 2018. https://www.census.gov/quickfacts/kerncountycalifornia.

Appendix A

Reference Survey

1. Why did you come to the library today? (Choose 1)

To do homework

I took workshop(s) for extra credit

My class had a library orientation here

I use the computers to go online or write papers

I print papers for class or use the copy machines

To find books

To use the databases to find articles

To ask librarians for research help

Other:

2. About how often would you say you use the library?

This is my first time here

1-2 times per semester

1-2 times per month

1-2 times per week

Daily

3. What are some of the most common reasons why you use the library? (Choose up to 3)

To do homework

I took workshop(s) for extra credit

My class had a library orientation here

I use the computers to go online or write papers

I print papers for class or use the copy machines

To find books

To use the databases to find articles

To ask librarians for research help

Other:

4. Is this the first time you've asked a reference librarian a question?

Yes

No

5. Did you feel as though the librarian helped you with your question?

Yes

No

Kind of

6. How likely are you to ask librarians for help the next time you have a research question?

Very likely

Likely

Not very likely 
Not likely at all

7. Do you ever use the resources on the library website (EBSCOhost, the library catalog, etc.) from your home computer, cell phone, or other off-campus computers?

Yes

No

I don't have access to a computer off-campus

8. (Only appears if yes) Have you ever needed help while doing research off-campus?

Yes

No

9. (Only appears if yes) Have you called the reference desk to ask for help while doing research offcampus?

Yes, I call a lot

Yes, I have called once or twice

No, the library was closed when I needed help

No, I hate talking on the phone

No, I didn't know I could call and get research help

Other:

10. Do you feel that librarians are available for help most of the time you are on campus?

Yes

No, I need help on weekends

No, I need help later in the evening

Other:

Appendix B

Library Orientation Faculty Feedback Survey

1. Based on the instruction you received, did the orientation meet your expectations?

Agree

Somewhat agree

Somewhat disagree

Disagree

N/A

2. The library instruction session was appropriate for the course level and assignment.

Agree

Somewhat agree

Somewhat disagree

Disagree

N/A

3. Electronic and/or print sources relevant to the course were identified and demonstrated.

Agree

Somewhat agree 
Somewhat disagree

Disagree

N/A

4. Do you routinely request library instruction for the courses you teach?

Yes

No

5. If you answered yes to the previous question, have you noticed an improvement in your students' research papers or assignments as a result of the library instruction?

Yes

Somewhat

No

6. Please rate the overall session

Very effective

Somewhat effective

Somewhat ineffective

Ineffective

NA

7. What did you particularly like about the session?

8. Suggest one change that would have improved the library instruction session.

Appendix C

Faculty Survey

1. The following questions were asked via table so that they were visible as one question with several parts

a. Have you ever brought a class to the BC library for a research orientation tailored to your class' research needs?

Yes, I do this every semester

Yes, I have done it once or twice before

No, I don't think this will benefit my students

No, I didn't know I could do this

Other:

b. Do you tell your students about the library's research skills workshops?

Yes

No

I didn't know these existed

I don't think they're helpful for my students

c. Have you ever asked a librarian to order books for the library that would be useful for your students or for your research?

Yes 
No

I didn't know I could do this

d. Have you ever placed a textbook for your course on reserve at the library?

Yes

No

I don't know what this means

2. Do you have any suggestions or feedback for the library?

\section{Appendix D}

General Student Survey

1. Have you been to the library while you've been a student at BC? (If answer is no, skip to question 38)

Yes

No

2. About how often do you use the library?

1-2 times per semester

1-2 times per month

1-2 times per week

Daily

3. What is the most common reason you use the library? (Check up to 2 options)

To do homework

I took workshop(s) for extra credit

My class had a library orientation here

I use the computers to go online or write papers

I print papers for class or use the copy machines

To find books

To use the databases to find articles

To ask librarians for research help

4. Do you use the library as a quiet space to do your homework? (If answer is no, skip to question 5)

Yes

No

5. Have you ever used the computers at the library? (If no, skip to question 8)

Yes

No

6. What do you mostly use the computers for? (Check one)

Going online to check my email

Going online to use social media such as Facebook or Twitter

Going online to use different websites for class

Doing research using the library databases (EBSCOhost, etc.) or the library catalog 
7. Do you think there are enough computers for students to use in the library?

Yes

No

8. Have you ever asked a librarian a question? (If no, skip to question 13; if I'm scared to ask, skip to 12)

Yes

No

I'm scared to ask

9. What kind of questions have you asked the librarians?

Technical (how to print, how to copy, how to use the computers)

Reference (how to look up books or articles, whether we have a certain book in the library, what search terms to use)

General (Where's the bathroom? Do you have a stapler?)

10. Are the librarians helpful when you ask them reference questions?

Yes

No

11. Have you ever been nervous or scared to ask the librarians a question? (If answer is no, skip to 13)

Yes

No

12. Why have you been scared to ask the librarians a question?

They might think my question is dumb

They probably won't know the answer

I don't know them

I feel overwhelmed by the library

13. Have you ever been in a class that has come to the library for a research orientation with a librarian? (If no, skip to question 24)

Yes

No

14. How much did you feel this orientation helped you find and evaluate research sources for your class(es)?

It helped a lot

It helped a little

It didn't help very much

It didn't help at all

15. Have you ever attended a workshop at the library? (If no, skip to 19)

16. Which workshops have you attended? (Check all that apply)

Strategies for Effective Research 
Finding Books \& eBooks

Finding Periodicals Online

Beyond Basic Google

Evaluating Internet Sources

Ethics of Research/Avoiding Plagiarism

17. Why did you attend this workshop?

My professor required me to attend

My professor gave extra credit for attending

EOP\&S, Financial Aid, Early Alert, or Student Life required that I attend

I wanted to learn more about using the library or researching

18. How helpful was this workshop for the research you need to do at BC?

Very helpful

Helpful

Not very helpful

Not helpful at all

19. Have you ever taken LIBR B1: Introduction to Library Research? (If no, skip to 22)

Yes

No

20. Why did you take this class?

My professor encouraged me to/offered extra credit if I took it

I wanted to learn how to research better

I needed an extra unit

21. After taking this class, how confident are you in your ability to find and evaluate research sources?

Very confident

Confident

Not very confident

Not confident at all

22. Have you ever checked a book out from the library? (If no, skip to question 24)

Yes

No

23. When you check out books, are they reserve books (textbooks that you get downstairs) or general books (books from the shelves upstairs)?

Reserve books

General books

24. Have you ever used the library catalog to look up books that we have in the library? (If no, skip to question 26)

25. Where did you learn how to use the library catalog? 
I asked a librarian

A professor showed me

I went to a library workshop

My class came to the library and a librarian showed us how to use it

I figured it out myself

26. Have you ever used one of the library databases (such as EBSCOhost or Opposing Viewpoints) to find articles? (If no, skip to end)

Yes

No

27. Which databases have you used before?

(insert list of databases)

28. Which database do you use the most?

(insert list of databases)

29. Where did you learn how to use the library databases?

I asked a librarian

A professor showed me

I went to a library workshop

My class came to the library for an orientation

I figured it out myself

Thank you for completing this survey! Your information will be extremely helpful. 